LUNDBERG, A.: Function of the ventral spinocerebellar tract - a new hypothesis.

J. Appl. Neurol., 30, 1, 1971:

MEISS, R. A.: An isometric muscle force transducer.

J. Neurosurg., 34, 2, Feb., 1971:

Meyer, G. A., Berman, I. R., Doty, D. B., et al.: Hemodynamic responses to acute quadriplegia with or without chest trauma.

Ned. tijd. voor fisio., April, 1971:

Meulman, H. D.: Fysiotherapie in de hartrevalidatie.

Ibid., May, 1971:

Stoppelman, M. R. H.: Cystic Fibrosis.

MinNigH, E. C.: L-Dopa revisited 1970; the medical and physical treatment of Parkinson's disease (in English).

\section{BOOK REVIEWS}

\section{MOBILIZATION AND MANIPULATION OF THE SPINE-BASIC TECHNIQUES. Author: Ian B. Sim.}

N.Z.R.P. Post-graduate Tutor, Christchurch Hospital, New Zealand. Edition: First. Pages: 28. Illustrations: 18. Publication Date: 1971. Publishers: The New Zealand Society of Physiotherapists. Price including Postage: $\$ 1.00$ (N.Z.). Copies obtainable from: The Editor, N.Z. Journal of Physiotherapy, "Woodchester", Waiau, North Canterbury, New Zealand.

This booklet is published from a series of articles printed in The New Zealand Journal of Physiotherapy from November 1968 to November 1970. It is divided into four sections, viz., the Cervical Spine, the Cervico-Thoracic Junctional area, the Thoracic Spine and the Lumbar Spine, and basic procedures are described for each region.

The author has omitted to stress the basic importance of the "neutral" position of the joint to be treated. This "neutral" joint position must be found, and maintained throughout the procedure, otherwise localization of the exact level ceases to exist.

I would prefer the use of the term "Passive Intervertebral Movements" to apply to certain articulations described by the author and would use them as an adjunct to examination and assessment primarily, before resorting to their use as treatment techniques.
The uses of his techniques are clearly stated, although some of the statements made are broad and not sufficiently explained. These statements are helpful mostly to those who have more background knowledge of examination and pathology than is given in this booklet.

Mention must be made of the extreme clarity of the author's description of techniques and the excellent explanatory photographs. However, one must remember that these are merely aids to learning the techniques and never a substitute for practical training. The author, in fact, states quite clearly in the preface that the techniques of mobilization and manipulation described and illustrated in this booklet are basic procedures and that these methods of treatment are used only when a complete pre-treatment examination has indicated their value. These remarks, made by the author, should be borne in mind when reading this booklet.

M. E. Murphy.

JAMIESON'S ILLUSTRATIONS OF REGIONAL ANATOMY. Section IV PELVIS, Ninth Edition. Revised by Walmsley and T. R. Murphy. E. \& S. Livingstone, Edinburgh and London, 1971. Pp. 38 of Illustrated plates. U.K. Price, $£ 1$ net.

As a visual aid to learning this atlas may fulfil its purpose. The purpose being to assist under-graduate medical students where greater detail of this region is not required.

On the whole the use of colour contributes to defining the various anatomical structures this is especially true of the bony components of the pelvis. The colour scheme does tend to be rather harsh. Green has been used for colouring some ligaments, fascial sheaths and membrane, whilst the colours used for voluntary and involuntary muscles and other ligaments are not very distinctive. It is felt that this detracts from the visual impact of such a book.

The wire back binding facilitates references but the size of the pages do limit the size of the drawings which imposes a restriction on the clarity of some of the plates.

Some of the abbreviations used hardly contribute to brevity and do not assist the student in the spelling of anatomical terms.

This atlas is not considered to be an essential for the physiotherapy student nor for the post graduate physiotherapist interested in ante and post natal work or in gynaecological work. In the latter case sufficient detail is not given.

A.H.

\title{
O.V.S. HOSPITAALDIENSTE
}

\section{VAKATURE: FISIOTERAPEUT}

\section{PROVINSIALE HOSPITAAL, WELKOM}

Applikante moet oor kwalifikasies in Fisioterapie beskik wat registreerbaar is by die S.A. Geneeskundige en Tandheelkundige Raad.

Aansoeke op vorm H.P. 8, verkrygbaar by hospitale in die O.V.S., moet regstreeks gerig word aan die Mediese Superintendent van bogemelde inirigting. 